\title{
Study of the Metabolism in vitro of Glucose in the Rat Epididymal Fat Tissue.
}

\author{
Stimulating Effect of Palmitic Acid*,**
}

\author{
N. Zaragoza and J.-P. Felber
}

Department of Clinical, Biochemistry, University of Lausanne, Lausanne, Switzerland

Received: October 11, 1968

Summary. The rat epididymal fat tissue was incubated with glucose differently labelled with ${ }^{14} \mathrm{C}$, and the effect of palmitate bound to albumin was studied in the absence or presence of insulin. No inhibition by palmitate of the glucose metabolism was observed. On the contrary, it was demonstrated that palmitate stimulates the different pathways of the glucose metabolism, particularly the fatty acid neosynthesis. The results are discussed in relation to the glucose and palmitate metabolism in the adipose cell, and in relation to the role in vivo of the adipose tissue in the decrease of the glucose assimilation observed in conditions which abnormally increase the serum level of free fatty acids.

Etude du métabolisme du glucose in vitro dans le tissu épididymaire du rat. Effet stimulant de l'acide palmitique

Résumé. Lo tissu adipeux épididymaire du rat a été incubé avec du glucose différemment marqué au ${ }^{14} \mathrm{C}$ et l'effet du palmitate lié à l'albumine a été étudié en l'absence et en présence d'insuline. Aucune inhibition, par le palmitate, du métabolisme du glucose n'a été observée; au contraire, il a été démontré que le palmitate stimule les différentes voies du métabolisme du glucose, en particulier la néosynthèse des acides gras. Les résultats sont discutés en fonction du métabolisme du glucose et du palmitate dans la cellule adipeuse, et en fonction du rôle tenu in vivo par le tissu adipeux dans la diminution de l'assimilation du glucose observée dans des conditions qui élèvent anormalement le taux des acides gras libres sériques.

Untersuchungen zum Glucose-Stoffwechsel des epididymalen Fettgewebsanhangs der Ratte in vitro. Zum Stimulationseffekt von Palmitinsäure.

Zusammenfassung. Das epididymale Fettgewebe der Ratte wurde mit verschieden markierter ${ }^{14} \mathrm{C}$-Glucose inkubiert, und der Effekt von mit Eiweiß gebundenem Palmitat in $\mathrm{Ab}$ - und Anwesenheit von Insulin untersucht. Es wurde keine Hemmung des Glucosemetabolismus durch Palmitat beobachtet; hingegen wurde erwiesen, daß Palmitat die verschiedenen Wege des Glucosemetabolismus anregt, besonders die Neosynthese der Fettsäuren. Die Resultate werden wie folgt diskutiert: 1 . im Hinblick auf den Metabolismus von Glucose und Palmitat in der Fettzelle, 2. im Hinblick auf die in vivo-Rolle des Fettgewebes bei der Verminderung der Glucoseassimilierung. Diese Verringerung wurde unter Bedingungen beobachtet, die den Serumspiegel der freien Fettsäuren ungewöhnlich stark erhöhen.

Key-words: Glucose, insulin, palmitate, fatty acids, $\mathrm{CO}_{2}$, glycogen, lipogenesis, esterification.

\section{Introduction}

An alteration in glucose tolerance has often been shown under experimental and pathological conditions where there was an abnormal elevation of serum $\mathrm{FFA}^{1}$ : fasting or a lack of carbohydrates $[45,14,30]$; infusion of a lipolytic hormone such as growth hormone [53, $31,63]$ or norepinephrine [50]; infusion of an emulsion of triglycerides [18]; ingestion of a meal rich in fat, followed by an injection of heparin [59]; repeated injections of glucagon [19] etc.; and lastly, diabetes and obesity $[30,6,1,20]$.

This observation led RandeE et al. $[55,56]$ to put forward the hypothesis of the "glucose-fatty acid cycle" in which a diminished peripheral utilization of glucose is caused by high serum FFA levels.

The blood glucose level depends, on the one hand, upon the uptake of glucose by the peripheral tissues, especially muscle and adipose tissue, and on the other

* This work was supported by a grant of the "Fonds National Suisse de la Recherche Scientifique" (request No. 4325).

** We should like to thank Miss M. Plattendurg for her technical assistance.

1 Free Fatty acids. hand, upon the variations in the balance of glycolysisgluconeogenesis in the liver.

In perfused heart and in incubated diaphragm of the rat $[51,54,25,26]$, the inhibition in vitro of glycolysis by long chain fatty acids has been well established $[51,54,25,26,61]$.

In the perfused liver, the inhibition by free fatty acids of certain key enzymes of glycolysis [68], the inhibition of acetyl-CoA carboxylase $[8,47]$ and of lipogenesis [37], and a stimulation of gluconeogenesis were observed $[23,65,17,11]$.

In vivo, however, SEYFFERT et al. [64] showed that though a sharp rise in FFA levels decreases the peripheral utilization of glucose, it also decreases the release of glucose by the liver; but they considered this last effect secondary to an increased release of insulin and a decreased secretion of glucagon.

The role of adipose tissue in the peripheral utilization of glucose is likely to be important, but is generally little taken into account. It has been mentioned that about $90 \%$ of glucose carbon retained in the body is kept in reserve in the form of fat [62].

The changes provoked by fatty acids in the glucose metabolism of adipose tissue have been less studied 
than those in other tissues. Using very high levels of fatty acid, outside the physiological range, LeBowUF and CAHILL [41] showed an increased uptake of glucose and an inhibition of the synthesis, stimulated by insulin, of fatty acids and of glycogen. Other workers found no effect in vitro of free fatty acids on glucose metabolism in adipose tissue $[24,27]$.

The purpose of our work was to complete these observations in the hope of proposing a mechanism by which the metabolism of free fatty acids could influence that of glucose in adipose tissue.

\section{Materials and Methods}

Wistar rats WAG, of 170 to $200 \mathrm{~g}$, received a glucose-rich diet for 10-15 days before the experiment. The epididymal adipose tissue from each of 12 rats was rapidly removed, cut into 6 fragments and placed in previously weighed flasks containing the complete incubation medium. Normally 24 incubation flasks were prepared for each experiment, and the pieces randomized so that in the end each bottle contained 6 different pieces from 6 different rats. The bottles were again weighed and the tissue weight determined by the difference.

The incubation medium was Krebs-bicarbonate buffer (KRB) containing $2 \%$ albumin (Armour, Bovine Serum Albumin powder, Fraction V) purified of free fatty acids according to GoodMAN [28], with a final concentration of free fatty acids always below $50 \mu \mathrm{val} / \mathrm{l}$.

The binding of palmitic acid to albumin was effected in two different ways:

1. at $40^{\circ} \mathrm{C}$ by adding drop by drop, a hot solution of potassium palmitate (prepared by precipitating it from an alcoholic solution of palmitic acid by the addition of $\mathrm{KOH})$ to a solution of albumin in the buffer, kept at a temperature of $40^{\circ} \mathrm{C}$.

2. or at $4^{\circ} \mathrm{C}$ by slow rotation over a period of $48 \mathrm{~h}$ of a balloon flask containing the $2 \%$ albumin solution on a thin bed of palmitic acid, obtained by evaporating under vacuum a solution of palmitic acid (Fluka) in ethanol.

The levels of palmitate in these preparations were measured by titration [16].

All the incubation media were dialyzed twice at $4^{\circ} \mathrm{C}$ against 20 volumes of buffer (immediately before the experiment). Dialysis tubing was previously treated by boiling in distilled water for a period of two hours.

Insulin (crystalline bovine insulin, Burroughs Wellcome and Co.), $1 \mathrm{U} / \mathrm{ml}$, which was conserved at $-20^{\circ} \mathrm{C}$ in a slightly acid solution, was diluted with the incubation medium.

Three types of labelled glucose were used: glucoseU. ${ }^{14} \mathrm{C}$, glucose-1-14 $\mathrm{C}$, glucose-6- ${ }^{14} \mathrm{C}$ (Radiochemical Centre, Amersham). About $1 \mu \mathrm{c}$ of radioactivity was added to each incubation flask.
After two hours of incubation, in an atmosphere of $95 \% \mathrm{O}_{2}+5 \% \mathrm{CO}_{2}, 0.4 \mathrm{ml}$ of hyamine hydroxide $(1 \mathrm{M})$ in methanol was added to a cup suspended inside the flask, $0.5 \mathrm{ml}$ of $3 \mathrm{~N} \mathrm{H}_{2} \mathrm{SO}_{4}$ was added to the medium. The flasks were shaken slowly for two hours, and the radioactive $\mathrm{CO}_{2}$ absorbed was measured.

After rinsing the tissues twice with $0.9 \%$ saline, the lipids were extracted and saponified according to FLATT and BaLL [21]. The fatty acids, extracted with petroleum ether and washed [21], were dried under vacuum, weighed and then dissolved in $3 \mathrm{ml}$ of heptane. The radioactivity in 2 aliquots, each of $0.1 \mathrm{ml}$, was measured.

The aqueous phase, after extraction of the fatty acids, contained the glycerol produced by the saponification of the lipids. The radioactivity of 2 aliquots, each of $0.5 \mathrm{ml}$, of this solution was measured without further purification.

The glycogen, prepared from tissue from which the fat had already been removed, was dissolved at $100^{\circ} \mathrm{C}$ in $1 \mathrm{ml}$ of $30 \% \mathrm{KOH}$, precipitated at $-20^{\circ} \mathrm{C}$ after addition of $1.3 \mathrm{ml}$ of ethanol $(95 \%)$, centrifuged, and the supernatant carefully eliminated. The precipitate was then dissolved in $\mathbf{2} \mathrm{ml}$ of distilled water. Radioactivity was counted in two $0.5 \mathrm{ml}$ aliquots. The total glycogen was measured in duplicate by the anthrone method in comparison with a glycogen standard.

The complete incubation medium combined with the saline from the two rinsings of the tissue was deproteinized by the addition of 1 volume of $0.66 \mathrm{M}$ $\mathrm{HClO}_{4}$, and the total volume adjusted in graduated. tubes. Glucose was measured by the o-toluidine method.

Radioactivity was measured in a Nuclear-Chicago Unilux 1 scintillation counter. For $\mathrm{CO}_{2}$, fatty acids and glycerol, a mixture of PPO, POPOP, ethanol and toluene was used. To this liquid was added Cab-O-Sil (Thixotropic Gel Powder, Packard) in quantities sufficient to stabilize the aqueous suspension obtained with the glycerol solution.

The radioactivity of glycogen was measured with Bray's scintillation medium [7]. The correction for quenching was carried out for each series of measurements. The quenching effect was determined by measuring under the same conditions, the radioactivity of two aliquots, each of $0.1 \mathrm{ml}$, of radioactive incubation medium of the experiment diluted $1: 10$. It was verified that the addition of different fractions of radioactivity caused a diminution of less than $2 \%$ in the counts $/ \mathrm{min}$. For the fatty acids, the percentage of quenching increased when the quantity of fatty acids per counting flask surpassed $20-25 \mathrm{mg}$. t-test.

All statistics were calculated according to Student's

\section{Results}

In all experiments the effects of insulin and palmitate, alone or in combination, on glucose-U-14 C metabolism have been compared, 
In the first experiments shown in Table 1, a preparation of the albumin-palmitate complex prepared at $40^{\circ} \mathrm{C}$ was used (see methods). No significant effect of this preparation on glucose metabolism was noted. The absence of the effect of increased glucose-U. ${ }^{14} \mathrm{C}$ incorporation into the glyceride-glycerol probably indicates that adipose tissue is not capable of esterifying in measurable quantities the palmitate complex prepared in this manner.

The preparations effected at $4^{\circ} \mathrm{C}$ (see methods), of which the maximum level of free fatty acids was variable and always inferior to that of hot preparations, changed significantly glucose-U ${ }^{14} \mathrm{C}$ metabolism (Table 1). In the presence of quite high concentrations of glucose, there was an increase in the incorporation of glucose into glyceride-glycerol, which indicates an esterification of palmitic acid by adipose tissue in both the presence and absence of insulin. An inhibition of fatty acid synthesis was never observed. On the contrary, in both the presence and absence of insulin, lipogenesis from glucose was increased in the presence of palmitate, and this effect was accompanied by a stimulation of the oxidation of glucose to $\mathrm{CO}_{2}$. How. ever, the synthesis of glycogen was not significantly changed by palmitate.

With low concentrations of glucose $(0.5 \mathrm{mg} / \mathrm{ml})$ the stimulation of glucose metabolism by palmitate was also seen.

When adipose tissue was incubated in the presence of two concentrations of palmitate, the increase in glucose metabolism due to palmitate was directly proportional to the level of palmitate in the incubation medium (Table 2). In certain experiments of this series the palmitate produced an increase in glycogen synthesis. This effect was not found to be reproducible in all experiments, and therefore will not be taken into consideration.

When adipose tissue was incubated with non-purified albumin, the content of FFA, although low $(107 \mu \mathrm{val} / 1$; control, $25 \mu \mathrm{val} / 1)$, was sufficient to exercise a remarkable stimulation of glucose metabolism $(\exp 2$, Table 2). In comparing the incubation medium containing gelatin as the base with that containing one of non-purified albumin, the same was observed, but only in the presence of insulin (exp. 4, Table 2).

Some experiments were carried out with two differently labelled substrates: glucose-1 ${ }^{14} \mathrm{C}$ and glucose$6{ }^{14} \mathrm{C}$ being compared in the same experiment (Table 3 ). Palmitate increased the incorporation of the 1st and the 6th carbons of glucose in the glyceride-glycerol fatty acids and $\mathrm{CO}_{2}$. Even when the oxidation of the 6 th carbon was increased by the palmitate, it remained low in absolute value.

The 6th carbon of glucose being oxidized exclusively in the Krebs cycle, the relative incorporation of this labelled carbon in $\mathrm{CO}_{2}$ and fatty acids is an indication of the relative importance of the 2 metabolic paths: the Krebs cycle and fatty acid neosynthesis, which are the two paths of acetyl-CoA utilization [40]. These calculations were made from the results of experiments 1 and 3 of Table 3. For each of the two parameters $\left(\mathrm{CO}_{2}\right.$ and $\left.\mathrm{FA}\right), 3$ measurements of the incorporation of glucose $-6 \cdot{ }^{14} \mathrm{C}$ were made per experiment The ratios and the corresponding means were calculated by combining these measurements according to all the pos. sibilities, 9 at the maximum (Table 4 ). The unexpected result is that the relative importance of fatty acid synthesis, compared with that of the Krebs cycle, was increased slightly, but significantly, by palmitate. This effect occurred in both the presence and the absence of insulin in the incubation medium.

\section{Discussion}

Table 1 shows that the effect of palmitate in vitro on the metabolism of glucose in adipose tissue depends upon the way the albumin-palmitate complex is prepared: the preparations made by adding warm potassium palmitate to a solution of albumin bring about no significant change, whereas those prepared in the cold, by prolonged contact of albumin solution with a thin layer of palmitic acid are "active", giving definite and reproducible results. Kesslek, Demeny and SoвоткA [39] have prepared the albumin-palmitate-

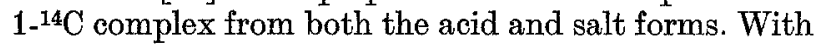
the preparation from the acid form, the uptake in vitro and turnover rate in vivo of palmitate are 2.5 and 2 times greater respectively than those with the second preparation. Goodman has established the existence of 3 types of binding between palmitate and serum albumin, with variable dissociation coefficients. One can suppose like KEssLER et al. [39], that the different preparations of the albumin-palmitate complex possess different binding characteristics favouring to a greater or lesser extent the exchange with adipose tissue, and also the secondary metabolic effects of that exchange.

The magnitude of the effects obtained with the "active" preparations of palmitate is related to the level of palmitate in the medium (Table 2).

Non-purified bovine albumin still contains a measurable quantity of FFA which can influence the metabolism of glucose in a manner comparable with preparations of the "active" complex (Table 2), and one can suppose that the FFA bound to albumin in plasma is likely to have similar effects on adipose tissue. However, one cannot exclude the possibility that GoodMAN's method for purifying albumin could remove, along with FFA, other impurities that might be responsible for the effects observed with non-purified albumin.

The conversion of glucose to glyceride-glycerol could constitute in certain conditions an indirect measure of esterification. That this is increased in the presence of FFA is, of course, expected.

Together with this effect, there is moreover, a more extensive metabolic stimulation, which also influences the paths of glucose oxidation and the synthesis of fatty acids; an increase in the synthesis of glycogen has 


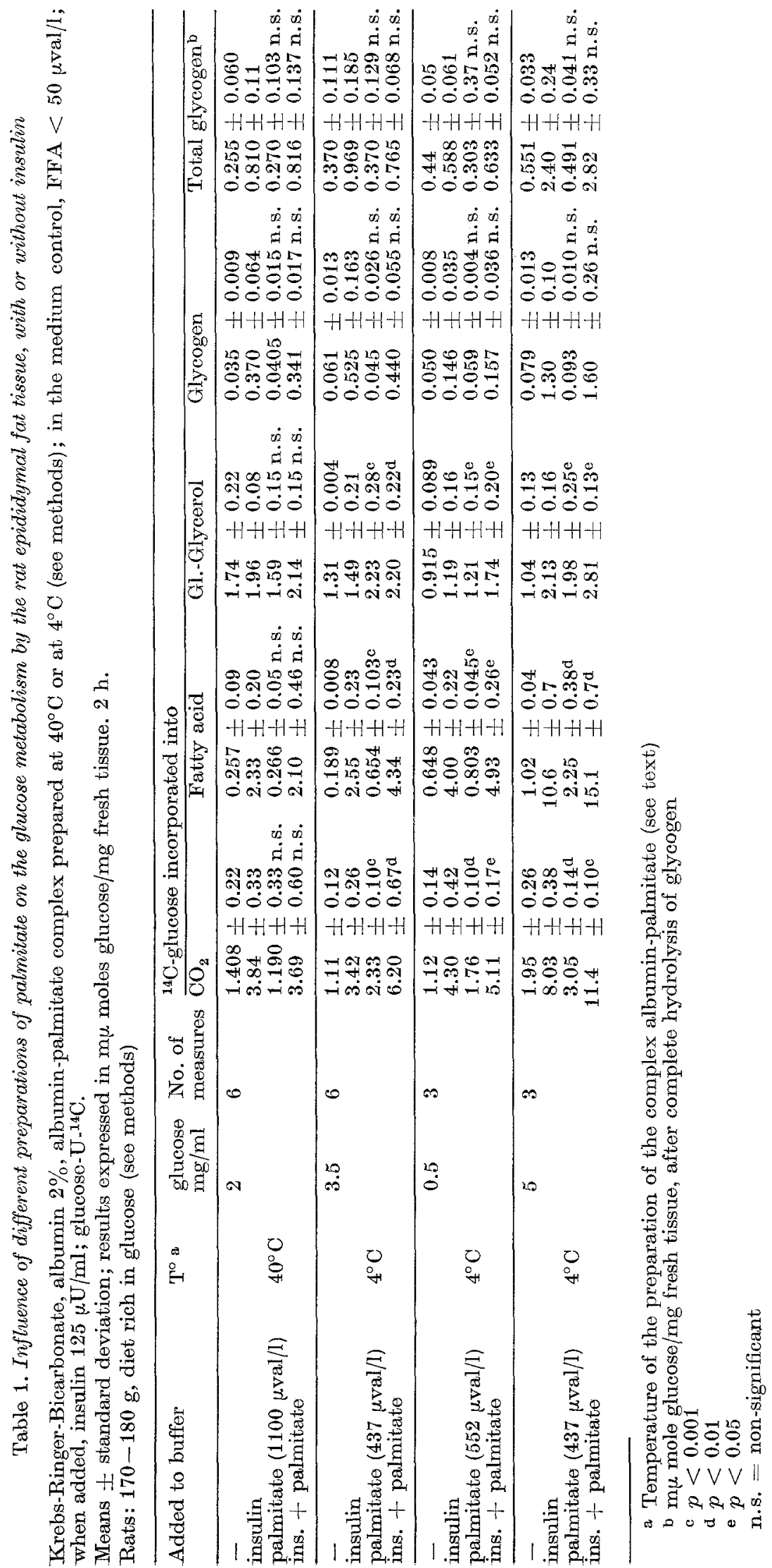


also been noted, but this was not observed in all experiments, and will not be further considered in the discussion. Similar effects were observed using animals placed in particular nutritional conditions : fasting 2 or 3 days or refeeding after fasting (unpublished results.) levels of palmitic acid in these experiments were very high: $4500 \mu \mathrm{val} / \mathrm{l}$ compared with 650 in the control medium.

On the basis of the results of LeBowUF and CAHILL [41] and with what occurs in the liver, it has been con-

Table 2. Measures of the glucose metabolism by the rat epididymal fat tissue in the presence of increasing concentrations of palmitate

Means \pm standard deviation of 4 values

The conditions of incubation are similar to those mentioned in Table 1. glucose $3.5 \mathrm{mg} / \mathrm{ml}$, + glucose U. ${ }^{14} \mathrm{C}$

\begin{tabular}{|c|c|c|c|c|}
\hline \multirow{2}{*}{$\begin{array}{l}\text { Insulin } \\
\mathrm{HU} / \mathrm{ml}\end{array}$} & \multirow{2}{*}{$\begin{array}{l}\text { Palmitate } \\
\mu v a l / I\end{array}$} & \multicolumn{3}{|c|}{${ }^{14} \mathrm{C}$-glucose incorporated into } \\
\hline & & $\overline{\mathrm{CO}_{2}}$ & Fatty acid & Gl-Glycerol \\
\hline- & $\begin{array}{l}-- \\
552 \\
818\end{array}$ & $\begin{array}{l}1.40 \pm 0.15 \\
2.15 \pm 0.13^{\mathrm{a}} \\
3.64 \pm 0.25^{\mathrm{a}, \mathrm{d}}\end{array}$ & $\begin{array}{l}0.505 \pm 0.030 \\
1.23 \pm 0.14^{\mathrm{b}} \\
1.62 \pm 0.35^{\mathrm{c}}\end{array}$ & $\begin{array}{l}1.16 \pm 0.10 \\
1.62 \pm 0.12^{\mathrm{c}} \\
2.02 \pm 0.16^{\mathrm{c}}\end{array}$ \\
\hline 125 & $\begin{array}{l}- \\
552 \\
818\end{array}$ & $\begin{array}{c}5.47 \pm 0.43 \\
8.31 \pm 0.65^{\mathrm{a}} \\
13.3 \pm 1.4^{\mathrm{a}} \\
\end{array}$ & $\begin{array}{cl}5.42 & \pm 0.43 \\
7.96 & \pm 0.20^{\mathrm{c}} \\
12.1 & \pm 1.0^{\mathrm{c}}\end{array}$ & $\begin{array}{l}1.29 \pm 0.04 \\
2.22 \pm 0.16^{\mathrm{b}} \\
3.56 \pm 0.19^{\mathrm{b}}\end{array}$ \\
\hline- & $\begin{array}{l}- \\
570 \\
1.128 \\
107^{\mathrm{e}}\end{array}$ & $\begin{array}{l}2.14 \pm 0.17 \\
4.74 \pm 0.45^{\mathrm{b}} \\
4.99 \pm 0.26 \mathrm{n} . \mathrm{s} . \\
3.56 \pm 0.17^{\mathrm{b}}\end{array}$ & $\begin{array}{l}1.16 \pm 0.13 \\
3.02 \pm 0.11^{\mathrm{b}} \\
\mathbf{3 . 6 1} \pm 0.18^{\mathrm{c}} \\
1.97 \pm 0.13^{\mathrm{a}}\end{array}$ & $\begin{array}{l}1.00 \pm 0.11 \\
1.70 \pm 0.14^{\mathrm{a}} \\
2.00 \pm 0.17 \mathrm{n} . \mathrm{s} . \\
1.44 \pm 0.14^{\mathrm{c}}\end{array}$ \\
\hline 125 & $\begin{array}{l}- \\
570 \\
1.128 \\
107 \mathrm{e} \\
\end{array}$ & $\begin{array}{l}10.2 \pm 0.12 \\
14.2 \pm 0.4^{\mathrm{a}} \\
19.5 \pm 0.7^{\mathrm{b}} \\
13.9 \pm 0.6^{\mathrm{a}} \\
\end{array}$ & $\begin{array}{ll}10.6 & \pm 0.5 \\
16.9 & \pm 0.8^{\mathrm{b}} \\
20.9 & \pm 0.9^{\mathrm{c}} \\
16.05 & \pm 0.94^{\mathrm{b}} \\
\end{array}$ & $\begin{array}{l}1.65 \pm 0.12 \\
2.69 \pm 0.10^{\mathrm{b}} \\
3.45 \pm 0.17^{\mathrm{a}} \\
2.23 \pm 0.11^{\mathrm{a}} \\
\end{array}$ \\
\hline- & $-\overline{-P}^{\mathrm{l}}$ & $\begin{array}{l}2.47 \pm 0.56 \\
2.21 \pm 0.05 \text { n.s. }\end{array}$ & $\begin{array}{l}1.18 \pm 0.11 \\
1.23 \pm 0.24 \text { n.s. }\end{array}$ & $\begin{array}{l}1.22 \pm 0.15 \\
1.51 \pm 0.16 \text { n.s. }\end{array}$ \\
\hline 125 & $\overline{114^{\mathrm{e}}}$ & $\begin{array}{r}7.07 \pm 0.67 \\
13.6 \pm 1.3^{b}\end{array}$ & $\begin{array}{cc}6.86 & \pm 0.76 \\
15.5 & \pm 2.0^{\mathrm{b}}\end{array}$ & $\begin{array}{l}1.19 \pm 0.05 \\
1.70 \pm 0.08^{b}\end{array}$ \\
\hline
\end{tabular}

a $p<0.01 \quad$ b $p<0.001 \quad$ c $p<0.05 \quad$ d compared with the mean concentration of palmitate

e non-purified albumin $2 \% \quad$ i gelatin $2 \%$, instead of albumin, FFA $<20 \mu \mathrm{val} / \mathrm{h}$ n.s. = non-significant

Table 3. Influence of palmitate on the $1 .{ }^{14} \mathrm{C}$-glucose and $6-{ }^{14} \mathrm{C}$-glucose

The conditions of incubation are similar

\begin{tabular}{|c|c|c|c|c|}
\hline \multirow[t]{2}{*}{ Added to medium } & \multicolumn{2}{|l|}{$\mathrm{CO}_{2}$} & \multicolumn{2}{|l|}{ Fatty acid } \\
\hline & $1-{ }^{14} \mathrm{C}-$ glucose & $6-{ }^{14} \mathrm{C}$-glucose & 1.14C-glueose & $6-\overline{14} \mathrm{C}-$ glucose \\
\hline $\begin{array}{l}\text { - } \\
\text { insulin } \\
\text { palmitate }(850 \mu v a l / 1) \\
\text { ins. + palmitate (id.) }\end{array}$ & $\begin{array}{c}2.31 \pm 0.06 \\
10.4 \pm 0.5 \\
3.81 \pm 0.21^{\mathrm{a}} \\
14.6 \pm 0.4^{\mathrm{a}}\end{array}$ & $\begin{array}{l}0.897 \pm 0.080 \\
1.09 \pm 0.07 \\
1.34 \pm 0.11^{\mathrm{b}} \\
1.28 \pm 0.07^{\mathrm{c}} \\
\end{array}$ & $\begin{array}{c}1.49 \pm 0.09 \\
6.87 \pm 0.19 \\
2.24 \pm 0.09^{\mathrm{a}} \\
10.1 \pm 0.5^{\mathrm{a}} \\
\end{array}$ & $\begin{array}{c}2.26 \pm 0.07 \\
13.1 \pm 0.6 \\
4.00 \pm 0.06^{\mathrm{a}} \\
21.2 \pm 2.1^{\mathrm{b}}\end{array}$ \\
\hline $\begin{array}{l}\text { insulin } \\
\text { palmitate }(818 \mu \mathrm{val} / 1) \\
\text { ins. + palmitate }\end{array}$ & $\begin{array}{c}1.60 \pm 0.12 \\
9.92 \pm 0.4 \\
4.39 \pm 0.56^{\mathrm{b}} \\
15.5 \pm 0.9^{\mathrm{a}}\end{array}$ & $\begin{array}{l}0.995 \pm 0.138 \\
1.126 \pm 0.165 \\
1.56 \pm 0.21^{\mathrm{c}} \\
1.71 \pm 0.14^{\mathrm{b}}\end{array}$ & & \\
\hline $\begin{array}{l}\text { - } \\
\text { insulin } \\
\text { palmitate }(748 \mu \mathrm{val} / 1)\end{array}$ & $\begin{array}{l}1.54 \pm 0.17 \\
7.03 \pm 0.81 \\
3.81 \pm 0.11^{\mathrm{a}} \\
13.4 \pm 0.4^{\mathrm{a}}\end{array}$ & $\begin{array}{l}0.94 \pm 0.03 \\
1.05 \pm 0.07 \\
1.20 \pm 0.04^{\mathrm{c}} \\
1.24 \pm 0.05^{\mathrm{c}}\end{array}$ & $\begin{array}{l}1.260 \pm 0.067 \\
5.62 \pm 0.32 \\
2.13 \pm 0.21^{\mathrm{b}} \\
9.16 \pm 0.26^{\mathrm{a}}\end{array}$ & $\begin{array}{l}2.05 \pm 0.19 \\
10.6 \pm 0.3 \\
4.06 \pm 0.21^{\mathrm{b}} \\
15.0 \pm 0.8^{\mathrm{a}}\end{array}$ \\
\hline
\end{tabular}

a $p<0.001$ b $p<0.01$ c $p<0.05$

These results are in part different from those of Leboevf and CamiLc [41]; on the one hand, they observed an increase, in the presence of FFA, of glucose uptake and glyceride-glycerol synthesis; and on the other, an inhibition, in the presence of insulin, of glucose conversion to glycogen and fatty acids. The cluded that there is in adipose tissue in vitro an inhibition of lipogenesis in the presence of FFA [70]. In no case do our results indicate inhibition; on the contrary, the inverse phenomenon is found, i.e. a stimulation of biosynthesis of fatty acids by tissue incubated with palmitate. A partial explanation of these apparently 
paradoxical results may be found in the generally accepted concept of compartmentation of tissue FFA in different and relatively independent pools $[66,38$, $15,4,58]$.

Winand, Furnetule and Christophe [69] have shown with epididymal adipose tissue of mouse in vitro that there are 3 pools: the FFA synthesized in vitro, the FFA coming from lipolysis and the FFA taken up from the medium. The FFA of the third pool do not inhibit the incorporation of newly formed fatty acids into lipids. Moreover, the tissue FFA play no role whatever in the assimilation and esterification of extratissular FFA [38, 15].

In a medium rich in FFA, particular oxidation of the sixth carbon of glucose has been mentioned [20,10]. Our results obtained using as substrate glucose labelled in positions 1 and 6 do not correspond with this observation. If palmitate stimulates the incorporation of both the 1st and 6 th carbon into $\mathrm{CO}_{2}$, the oxidation of the 6 th carbon is of little importance.

The oxidation of the 6th carbon is exclusively reserved for the Krebs cycle and is little stimulated by insulin or palmitate (Table 3). By comparing the incorporation of the 6 th carbon into $\mathrm{CO}_{2}$ and fatty acids, one can estimate the relative rate of the Krebs cycle and fatty acid synthesis (Table 4). Insulin channels acetyl-CoA in the direction of lipogenesis, thus restraining its utilization by the Krebs cycle. The action of palmitate, though smaller, acts in the same way, and accelerates the synthesis of fatty acids more than that of the Krebs cycle. The percentage of glucose utilization by the pentose cycle was calculated from
In other papers a particualr importance was given to citrate, the level of which influences the activity of several important enzymes of glucose metabolism. In the perfused heart or in the diaphragm incubated in a medium rich in fatty acids, GARLAND and RANDLE [26] have measured an increase of the citrate level, caused by an excess of acetyl-CoA due to a fast oxidation of fatty acids of the medium or of the perfusate. By the inhibition of phosphofructokinase, citrate might contribute in the muscle to the slowing down of glycolysis observed in the presence of FFA [26].

In the normal adipose tissue incubated in the presence of glucose, the oxidation of exogenous fatty acids is of little importance $[5,60]$ and would be unlikely to furnish a sufficient source of acetyl-CoA and citrate. Denton et al. [12] have observed an increase in the citrate level in adipose tissue under the infiuence of adrenaline or alloxan diabetes. Moreover, even if it were demonstrated that citrate accelerates in vitro the acetyl-CoA-carboxylase of the liver [48] and of the adipose tissue [46], citrate is also an inhibitor of the phosphofructokinase extracted from adipose tissue [13]; and these two effects would have an inverse relationship in the neosynthesis of fatty acids in this tissue. The physiological effect of citrate thus becomes difficult to establish.

In normal adipose tissue, practically all the FFA taken up from the medium are esterified [60], and the degree of esterification is related to the concentration of FFA in the incubation medium [5].

Before esterification the FFA must be activated by $\mathrm{CoA}$ to give acyl-CoA, and this process needs energy in

metabolism by the rat epididymal fat tissue

to those mentioned in Table 2.

\begin{tabular}{|c|c|c|c|}
\hline Gl-Glycerol & & Glycogen & \\
\hline $1-{ }^{14} \mathrm{C}-g l u \cos \theta$ & $6-{ }^{14} \mathrm{C}$-glucose & $1-{ }^{14} \mathrm{C}$-glucose & ${ }^{6-14} \mathrm{C}$-glucose \\
\hline $0.798 \pm 0.043$ & $0.776 \pm \mathbf{0 . 0 5 3}$ & $0.076 \pm 0.009$ & $0.076 \pm 0.008$ \\
\hline $1.09 \pm 0.06$ & $1.37 \pm 0.21$ & $1.32 \pm 0.15$ & $1.36 \pm 0.14$ \\
\hline $0.966 \pm 0.056^{\mathrm{c}}$ & $1.16 \pm 0.07^{\mathrm{b}}$ & $0.076 \pm 0.012 \mathrm{n} . \mathrm{s}$. & $0.080 \pm 0.010$ n.s. \\
\hline $1.58 \pm 0.10^{\mathrm{b}}$ & $2.21 \pm 0.05^{\mathrm{b}}$ & $1.63 \pm 0.13 \mathrm{n} . \mathrm{s}$. & $1.50 \pm 0.15$ n.s. \\
\hline $1.29 \pm 0.17$ & $1.45 \pm 0.09$ & $0.068 \pm 0.027$ & $0.061 \pm 0.013$ \\
\hline $1.37 \pm 0.07$ & $1.82 \pm 0.07$ & $0.863 \pm 0.014$ & $0.865 \pm 0.115$ \\
\hline $2.000 \pm 0.09^{b}$ & $1.96 \pm 0.12^{c}$ & $0.106 \pm 0.045$ n.s. & $0.111 \pm 0.025$ n.s. \\
\hline $2.58 \pm 0.16^{\mathrm{a}}$ & $2.66 \pm 0.20^{\mathrm{b}}$ & $1.012 \pm 0.09$ n.s. & $1.09 \pm 0.22$ n.s. \\
\hline $0.913 \pm 0.057$ & $1.04 \pm 0.09$ & $0.073 \pm 0.003$ & $0.065 \pm 0.016$ \\
\hline $1.07 \pm 0.05$ & $1.32 \pm 0.04$ & $0.854 \pm 0.084$ & $0.899 \pm 0.071$ \\
\hline $1.49 \pm 0.11^{\mathrm{a}}$ & $1.42 \pm 0.03^{\mathrm{b}}$ & $0.076 \pm 0.004$ n.s. & $0.081 \pm 0.011$ n.s. \\
\hline $1.63 \pm 0.03^{\mathrm{a}}$ & $2.035 \pm 0.05^{\mathrm{a}}$ & $1.09 \pm 0.06$ n.s. & $1.07 \pm 0.08$ n.s. \\
\hline
\end{tabular}

the incorporation of the first and sixth carbons of glucose into $\mathrm{CO}_{2}$ and fatty acids, following the methods of KATz etal. [36], and it appeared to be unmodified or slightly raised by the presence of palmitate. This is in agreement with the above mentioned stimulation of the lipogenetic pathway. the form of ATP. The source of ATP is in cellular respiration by oxidative phosphorylation of reduced coenzymes, at the mitochondrial level. BALI and JUNGAS [2] have established experimentally a proportional relation between the quantity of fatty acid esterified and the oxygen consumed by adipose tissue. 
What is the origin of the reduced coenzymes, the oxidation of which furnishes energy? The oxidation of fatty acids, being low in normal adipose tissue, cannot constitute, as in muscle, an important source of reduced coenzymes. During the reactions which lead to the synthesis of fatty acids from glucose, the adipose tissue produces and consumes reduced coenzymes. FLATT and BALL [21] have calculated the balance, and have shown that adipose tissue produces an excess of reduced coenzymes, the quantity of which corresponds very well to the uptake of oxygen measured during this process. These authors then put forward the hypothesis that "one controlling factor in the synthesis of fatty acids from glucose may be ... the rate at which high energy phosphate is needed by the cell."

In the light of this hypothesis, the effect on glucose metabolism produced in vitro by the FFA, becomes
The interpretation of the results of this study on a physiological level, leads to the idea that, in all cases where the serum levels of FFA have been increased in vivo by an exterior process without a direct influence on lipolysis (infusion of an emulsion of triglycerides [18], ingestion of a meal rich in fat followed by an injection of heparin $[59,64]$ ) the adipose tissue more than likely plays no part in the decrease of peripheral utilization of glucose.

In experimental situations where the serum FFA levels are acutely increased by infusions of lipolytic hormone, such as growth hormone or norepinephrine $[53,31,63,50]$, the abnormal evolution of the glycaemia does not seem to have any relation to a diminished utilization of glucose by the adipose tissue. Indeed, the uptake of glucose in vitro is increased by growth hormone $[34,42]$, and by adrenaline [10,67]

Table 4. Influence of palmitate on the percentage utilization of acetyl-CoA in the Krebs cycle and the fatty acid synthesis calculated from results of Table 3

$100 \%=$ carbon incorporated in $\mathrm{CO}_{2}+$ carbon incorporated in fatty acids. means \pm S.E.M.

\begin{tabular}{lrl}
\hline Added to buffer & \multicolumn{2}{c}{ Percentage utilization of acetyl-CoA by } \\
\cline { 2 - 3 } & \multicolumn{1}{c}{ Krebs cycle } & fatty acid synthesis \\
\hline insulin & $28.90 \pm 0.370(6)^{\mathrm{a}}$ & $71.08 \pm 0.360(6)$ \\
palmitate $(850 \mu v a 1 / 1)$ & $8.35 \pm 0.158(9)$ & $91.63 \pm 0.158$ \\
insulin + palmitate (id.) & $25.13 \pm 0.451(9)^{\mathrm{b}}$ & $74.85 \pm 0.444^{\mathrm{b}}$ \\
\hline & $5.72 \pm 0.150(9)^{\mathrm{b}}$ & $94.27 \pm 0.159^{\mathrm{b}}$ \\
\hline insulin & $31.62 \pm 0.597(9)$ & $68.37 \pm 0.599(9)$ \\
palmitate (748 pval/l) & $9.00 \pm 0.180(9)$ & $91.00 \pm 0.180(9)$ \\
insulin + palmitate (id.) & $26.47 \pm 0.480(9)^{\mathrm{b}}$ & $73.5 \pm 0.471(9)^{\mathrm{b}}$ \\
\hline
\end{tabular}

a number of values (see text)

b $p<0.001$

clearer. In this particular case, the adipose cell uses energy while it esterifies the fatty acid of the medium. The energy used by this process of esterification brings about an acceleration of glucose metabolism, in particlar in the direction of fatty acid synthesis, thus producing an increase in the production of reduced coenzymes. The excess, not used in reduction reactions, is oxidized by molecular $\mathrm{O}_{2}$, thus restoring the ATP reserves.

In conclusion the results of this study have shown that in vitro, the FFA do not diminish the utilization of glucose by adipose tissue, and, in particular, exercise no inhibiting action on the synthesis of fatty acids from glucose. It can be shown, on the contrary, that there is a certain stimulation of glucose metabolism by the FFA, explicable on an energetic basis.

These observations do not exclude the hypothesis of an inhibition of lipogenesis by high levels of intracellular FFA [43 and 44], even though this effect has not yet been directly demonstrated. Measurements of FFA, which are yet to be published, allowed us to establish the absence of a relation between the levels of FFA in the tissue and their concentration in the medium, which accelerates particularly lipogenesis [21]. The tissular levels of FFA, elevated in the presence of adrenaline alone, are rapidly reduced to normal values by glucose and insulin together [35]. A decrease in glucose tolerance simultaneous with an increased serum level of FFA, is also observed during fasting, during deprivation of carbohydrates $[45,14,30]$, and in the alloxan diabetic state; and, in these conditions, the utilization of glucose in vitro by adipose tissue is seriously diminished $[57,38,42,71,33]$.

The cause of this metabolic inhibition may not be in direct relation with elevated FFA, levels of tissue but could be looked for in metabolic adaptation mechanisms of a more complex nature, probably related to insulin insufficiency [32], which could bring about under these conditions a decrease in the activity of certain important enzymes for the utilization of glucose $[52,3$, $72,29,40]$.

\section{References}

1. Andres, R., and K.L. ZrerLer: Spontaneous and insulin induced resistance of peripheral tissues to in. sulin in diabetes, Clin, Res, 6, 250-259 (1958). 
2. BALL, E.G., and R.L. JUNGAS: Some effects of hormones on the metabolism of adipose tissue. Recent Progr. Hormone Res. 20, 183-214 (1964).

3. - - Studies on the metabolism of adipose tissue. XIII. The effect of anaerobic conditions and dietary regime on the response to insulin and epinephrine. Biochemistry 2, 586-582 (1963).

4. Barly, P.B., H. Kapperrer, E.R. Froesch, and A. LABHART: Effects of glucose on spontaneous limitation of lipolysis in isolated adipose tissue. A potential regulatory mechanism. Ann. N.Y. Acad. Sci. 131, $143-156$ (1965).

5. Bally, P.R., G.F. Cahill, Jr., B. Leboevf, and A.E. RENoud: Studies on rat adipose tissue in vitro. V. Effects of glucose and insulin on the metabolism of palmitate-1 ${ }^{14} \mathrm{C}$. J. biol. Chem. 235, 333-336 (1960).

6. Bierman, E.L., V.P. Dole, and T.N. Roberts: An abnormality of nonesterified fatty acids metabolism in diabetes mellitus. Diabetes 6, 475-479 (1957).

7. BRAY, G.A.: A simple efficient liquid scintillator for counting aqueous solutions in a liquid scintillation counter. An. Biochem. 1, 279-285 (1960).

8. Bortz, W., and F. Lynen: The inhibition of acetylCoA carboxylate by long chain acyl-CoA derivatives. Biochem. Z. 337, 505-509 (1963).

9. BowmaN, B.H.: Effect of diabetes, fatty acids and ketone bodies on tricarboxylic acid cycle metabolism in the perfused rat heart. J. biol. Chem. 241, 3041 $3048(1966)$.

10. Cahtl工, G.F., Jr., B. LebowuF, and R.B. FitnN: Studies on rat adipose tissue in vitro. VI. Effect of epinephrine on glucose metabolism J. biol. Chem. 235, $1246-1250(1960)$.

11. Deliste, G., and I.B. FrITz: Interrelations between hepatic fatty acid oxidation and gluconeogenesis: a possible regulatory role of carnitine palmityl-transferate. Proc. nat. Acad. Sci. (Wash.) 58, 790-797 (1967).

12. Denton, M., R.E. Yorke, and P.J. Randet: Measurements of concentrations of metabolites in adipose tissue and effects of insulin, alloxan-diabetes and adrenaline. Biochem. J. 100, 407-419 (1966).

13. Denton, R.M., and P.J. Randle: Citrate and the regulation of adipose tissue phosphofructokinase. Biochem. J. 100, 420-423 (1966).

14. DoLe, V.P.: Relation between non-esterified fatty acids in plasma and the metabolism of glucose. $J$. clin. Invest. 35, 150-154 (1956).

15. - The fatty acid pool in adipose tissue. J. biol. Chem. 236, 3121-3124 (1961).

16. - , and H. MetNeRtz: Microdetermination of longehain fatty acids in plasma and tissues. J. biol. Chem. 235, 2595-2599 (1960).

17. Exton, J.H., and C.R. PARK: Control of gluconeogenesis in liver. $\mathrm{I}$. General features of gluconeogenesis in the perfused livers of rats. J. biol. Chem. 242, 2622-2636 (1967)

18. Felber, J.-P., and A. VANNotTI: Effects of fat infusion on glucose tolerance and insulin plasma levels. Med. Exp. 10, 153-156 (1964).

19. -, et A. VANNNotTI: Décompensation pancréatique et diabète. Rev. franç. Endocr. Clin. 7, 211-226 (1966).

20. - N. Zaragoza, L. Grassi, A.J. Moody et A. VarNotrr: Utilisation diminuée du glucose et accumulation de graisse chez l'obèse diabétique. Schweiz. med. Wschr. 96/47, 1575-1578 (1966).

21. FLATT, J.-P, and E.G. BALL: Studies on the metabolism of adipose tissue. XV. An evaluation of the major pathways of glucose catabolism as influenced by insulin and epinephrine. J. biol. Chem. 239, 675-685 (1964).
22. FREINKEL, N.: Extrathyroidal actions of pituitary thyrotropin: effects on the carbohydrate, lipid and respiratory metabolism of rat adipose tissue. J. clin. Invest. 40, 476-489 (1961).

23. Friedmann, B., E.H. Goodman, and S. Weinhouse: Effect of insulin and fatty acids on gluconeogenesis in the rat. J. biol. Chem. 242, 3620-3627 (1967).

24. Froesh, E.R., H. Bürgi, E.B. Ramseier, and A. LABHART: Antibody suppressible and non-suppressible insulin-like activities in human serum and their physiological significance. An insulin assay with adipose tissue of increased precicion and specificity. J. clin. Invest. 42, 1816-1834 (1963).

25. Gart.AND, P.B., E.A. NEWSHolme, and P.J. RandLE: Regulation of glucose uptake by muscle. 9. Effect of fatty acids and ketone bodies, and of alloxan-diabetes and starvation, on pyruvate metabolism and on lactate/pyruvate and L-glycerol 3 phosphate/dihydroxyacetone phosphate concentration ratios in rat heart and rat diaphragm muscles. Biochem. J. 93, 665-678 (1964).

26. - , and P.J. RANDLE: Regulation of glucose uptake by muscle. 10. Effect of alloxan-diabetes, starvation, hypophysectomy and adrenalectomy, and of fatty acids, ketone bodies and pyruvate, on the glycerol output and concentrations of free fatty acids, long. chain fatty-acyl-coenzyme A, glycerol phosphate and citrate-cycle, intermediates in rat heart and diaphragm muscles. Biochem. J. 93, 678-687 (1968).

27. GJEDDE, F.: Studies of the ILA of Serum. III. Influence of the Pancreas on the ILA of Serum. Acta endocr. (Kbh.) 57, 505-528 (1964).

28. Goodman, D.S.: The interaction of human serum albumin with long-chain fatty acid anions. J. Amer. chem. Soc. 80, 3892-3898 (1958).

29. Gromova, K.G.: Vop. med. Him. 6, 631-639 (1964).

30. Halass, C.N., and P.J. RANDLE: Effect of low carbohydrate diet and diabetes mellitus on plasma concentrations of glucose, non-esterified fatty acids and insulin during oral glucose tolerance test. Lancet $1963 \mathrm{I}$, $790-794$

31. Ikkos, D., R. Luft, C.-A. Gemzerr, and S. AlmovIST: Effect of human growth hormone on glucose tolerance and some intermediary metabolites in man. Studies in healthy subjects given human growth hormone and in patients with acromegaly. Acta endocr. (Kbh.) 39, 547-566 (1962).

32. IL'IN, V.S.: The mechanism of action of insulin: primary and secondary metabolic disturbances in experimental diabetes. Fed. Proc. 25, T 1034-1040 (1966).

33. Jearrenaud, B., and A.E. Renold: Studies on rat adipose tissue in vitro. VII. Effects of adrenal cortical hormones. J. biol. Chem. 235, 2217-2223 (1960).

34. JuNG.As, R.L., and E.G. BatL: Studies on the metab. olism of adipose tissue. V. The effect of a growth hormone preparation and insulin on the oxygen con. sumption, glucose uptake, and lactic acid production. J. biol. Chem. 235, 1894-1899 (1960).

35. - - Studies on the metabolism of adipose tissue. XII. The effects of insulin and epinephrine on FFA and glycerol production in the presence or absence of glucose. Biochemistry 2, 383-388 (1963).

36. Karz, J., B.R. Landau, and G.E. Bartsch: The pentose cycle, triosephosphate isomerization, and lipogenesis in rat adipose tissue. J. biol. Chem. 241, 727738 (1966).

37. KORCHAK, H.M., and E.J. Masoro: Free fatty acids as lipogenic inhibitors. Biochim. biophys. Acta 84, $750-753$ (1964).

38. KmRPEL, S., E. Shafrit, and B. SHAPIRo: Mechanism of fatty acid assimilation in adipose tissue. Biochem. biophys. Acta 46, 495-504 (1961). 
39. Kesslegr, J.I., M. Demeny, and H. SobotKa: Rates of tissue uptake of palmitic-1 ${ }^{14} \mathrm{C}$ complexed with albumin by two different procedures. J. Lip. Res. 8, $185-190(1967)$.

40. Leboeut, B., and G.F. CAhisu: The regulation of fatty acid synthesis and direct oxidative pathway in adipose tissue. Fed. Proc. 19, 226 (1960).

41. Studies on rat adipose tissue in vitro. VIII. Effect of preparations of pituitary adreno-corticotropic and growth hormone on glucose metabolism. J. biol. Chem. 236, $41-46$ (1961).

42. Leites, S.M., and N.K. Davtyax: Influence of glucose uptake by adipose tissue on its lipolytic activity during action of certain hormones and in experimental diabetes. Fed. Proc. 25, T 1009 (1966).

43. LeveiLle, G.: Control of lipogenesis in adipose tissue of fasted and fed meal-eating rats. J. Nutr. 92, 460466 (1967).

44. - Lipogenesis in adipose tissue of meal-fed rats. A possible regulatory role of $\alpha$-glycerophosphate formation. Canad. J. Physiol. Pharmacol 45, 201-213 (1967).

45. LUNDBAEOK, K.: Metabolic abnormalities in starvation diabetes. Yale J. Biol. Med. 20, 553-562 (1948).

46. Maritin, D.B., and P.R. VAGeloos: The mechanism of tricarboxylic acid cycle regulation of fatty acid synthesis. J. biol. Chem. 237, 1787-1792 (1962).

47. Masord, E. J.: Mechanisms related to the homeostatic regulation of lipogenesis. Ann. N.Y. Acad. Sci. 131, $199-205(1965)$.

48. Matsuhashi, M., S. Matsuhashi u. F. Liynen: Zur Biosynthese der Fettsäuren. V. Die Acetyl-CoA carboxylase aus Rattenleber und ihre Aktivierung durch Citronensäure. Biochem. Z. 340, 263-289 (1964).

49. MoLean, P., J. Brown, E. Walters, and GreinsLADEK: Effect of alloxan diabetes on multiple forms of hexokinases in adipose tissue and lung. Biochem. J. 105, 1301-1305 (1967).

50. Nestel, P.D., K.F. CARRILI, and M.S. Smverstein: Influence of free fatty acids metabolism on glucose tolerance. Lancet 1964 II, $115-117$.

51. Newsholme, E.A., and P.J. RANDLE: Regulation of glucose uptake by muscle. 7. Effect of fatty acids, ketone bodies and pyruvate, and of alloxan diabetes, starvation, hypophysectomy and adrenalectomy, on the concentration of hexose phosphates, nucleotides and inorganic phosphate in perfused rat hoart. Biochem. J. 93, 641-651 (1964).

52. Pogson, C.I., and R.M. Denton: Effect of alloxan diabetes, starvation and refeeding on glycolytic-kinase activities in rat epididymal adipose tissue. Nature (Lond.) 216, 156-157 (1967).

53. Rabein, M.S., and C.H. Hollexberg: Effect of growth hormone on plasma fatty acids. J. clin. Invest. 38, $484-488$ (1959).

54. RANDLe, P.J., E. A. Newsholme, and P.B. Gariand : Regulation of glucose uptake by muscle. 8. Effect of fatty acids, ketone bodies and pyruvate, and of alloxan-diabetes and starvation, on the uptake and metabolic fate of glucose in rat heart and diaphragm muscles. Biochem. J. 93, 652-665 (1964).

55. - P.B. Gartand, C.N. Hales, and E.A. NewsHoLME: The glucose-fatty acid cycle. Its role in insulin sensitivity and the metabolic disturbances of diabetes mellitus. Lancet 1963 I, 785-789.
56. - - E. A. NEwsHorme, and C.N. HALES: The glucosefatty acid cycle in obesity and maturity onset diabetes mellitus. Ann. N.Y. Acad. Sci. 131, 324-333 (1965).

57. RoDBELI, M.: Metabolism of isolated fat cells. I. Effect of hormones on glucose metabolism and lipolysis. J. biol. Chem. 239, 375-380 (1964).

58. Rubinstein, D., A.M. Daniet, S. Chiu, and J.-P. BECK: The effect of homogeneization on free and esterified fatty acid pools in adipose tissue. Canad. J. Biochemistry 43, 271-280 (1965).

59. Scrraldh, D.S., and D.M. KrPNIS: Abnormalities in carbohydrate tolerance associated with elevated plasma non-esterified fatty acids. J. clin. Invest. 44, 2010-2020 (1965).

60. Shapiro, B., I. Chowers, and G. Rose: Fatty acid uptake and esterification in adipose tissue. Biochim. biophys. Acta 23, 115-125 (1957).

61. ShIPP, J.C.: Interrelation between carbohydrate and fatty acid metabolism of isolated perfused rat heart. Metabolism 13, 852 (1954).

62. Silperstein, M.: In: Diabetes Moscow 90 (1964).

63. Stein, M.F., D.M. Kipnis, and W.H. DaUGHaday: The effect of human growth hormone on plasma insulin dynamics in man. J. Lab. clin. Med. 60, 1022 (1962).

64. Seytert, W.A., and L.L. Madison: Physiologic effects of metabolic fuels on carbohydrate metabolism. Diabetes 16, 765-776 (1967).

65. Teuferd, H., L.A. Menahan, J.C. Shipp, S. Böning, and $O$. WIELAND: Effect of oleic acid on the oxidation and gluconeogenesis from $\left(1-{ }^{14} \mathrm{C}\right)$ pyruvate in the perfused rat liver. Europ. J. Biochemistry 2, 182-186 (1.967).

66. VAUGHaN, M.: The metabolism of adipose tissue in vitro. J. Lip. Res. 2, 293-316 (1961).

67. Verner, J.V., W. G. Blackard, and F. Engmu: Some factors modifying the actions of hormones on glucose uptake by adipose tissue in vitro. Endocrinology 70, $420-428$ (1962).

68. Weber, G., H.J.H. Convery, M.A. LeA, and N.B. STAMm: Feedback inhibition of key glycolytic enzymes in liver: action of free fatty acids. Science 154, $1357-1360$ (1966).

69. Winand, J., J. Furinelde et J. Christophe: Métabolisme in vitro du tissu adipeux. V. Hétérogénéité et sub-hétérogénéité du pool des NEFA dans le tissu adipeux épididymaire de la souris normale. Effets in vitro du glucose, de l'adrénaline et de l'insuline. Bull. Soc. Chim. biol. (Paris) 49, 1331-1356 (1967).

70. Winegrad, A.E.: Adipose tissue in diabetes. Handbook of Physiology Section 5. Adipose tissue (A.E. Renold and G.F. Cahill Jr. eds.) chap. 32, pp. 319329 (1965).

71. Winegrad, A.I., and A.E. Renold: Studies on rat adipose tissue in vitro. I. Effect of insulin on the metabolism of glucose, pyruvate and acetate. J. biol. Chem. 233, 267-272 (1958).

72. Young, J.W., E. Shrago, and H.A. Lardy: Metabolic control of enzymes involved in lipogenesis and gluconeogenesis. Biochemistry 3, $1687-1692$ (1964).

\author{
N. Zaragoza \\ J.-P. FELBER \\ Department of Clinical Biochemistry \\ University of Lausanne \\ CH-1000 Lausanne
}

